\title{
Subsurface Application of Dry Poultry Litter: Impacts on Common Bermudagrass and Other No-Till Crops
}

\author{
Daniel H. Pote (Corresponding author) \\ USDA-ARS, DBSFRC, 6883 South State Hwy. 23, Booneville, AR 72927, USA \\ Tel: 479-675-3834 ext. $344 \quad$ E-mail: dan.pote@ars.usda.gov \\ Thomas R. Way \\ USDA-ARS, National Soil Dynamics Laboratory, Auburn, AL 36832, USA
}

Peter J.A. Kleinman

USDA-ARS, Pasture Systems and Watershed Management Research Unit, University Park, PA 16802, USA

Philip A. Moore

USDA-ARS, Poultry Production and Product Safety Research Unit, Fayetteville, AR 72701, USA

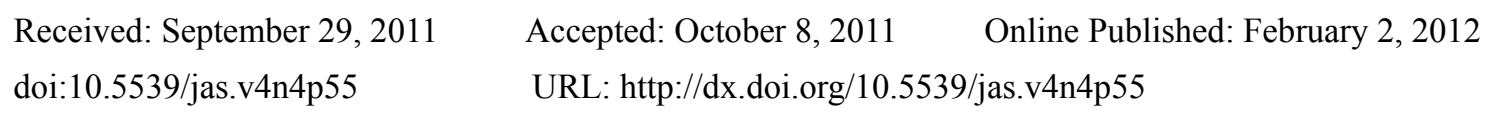

Mention of trade names or commercial products in this article is solely for the purpose of providing specific information and does not imply recommendation or endorsement by the USDA.

\begin{abstract}
Poultry manure provides a rich organic nutrient source to fertilize crops and help neutralize soil acidity. However, the usual practice of broadcasting litter on the surface of pastures and other no-till systems can degrade water quality by allowing nutrients to be transported from fields in surface runoff, while much of the ammonium-N volatilizes and escapes into the atmosphere. In a previous study, we used a subsurface banding technique to move litter from the soil surface into the root zone with minimal disturbance of the grass, thatch, and soil structure; and found that nutrient losses decreased substantially. Because subsurface banding increased retention of nutrients and water in the soil, we conducted follow-up research to compare crop yield and quality from this litter application method to those from the conventional surface broadcasting method. The objectives were to determine effects of subsurface application on perennial forage yield, quality, and temporal yield distribution during the growing season. Field plots were located on silt loam soil (8-10\% slopes) with well-established bermudagrass (Cynodon dactylon L. Pers.). Poultry litter was applied (6.7 $\mathrm{Mg} \mathrm{ha}^{-1}$, dry weight) by one of two methods: surface broadcast manually or subsurface banded using a tractor-drawn prototype implement. Each treatment was replicated three times. There were also three control plots that received no litter. Results showed that subsurface application generally increased forage quality and yield, especially in the latter part of the growing season when forage production from surface-applied litter began to decline. Under the growing conditions in this study, subsurface application increased mean forage yield by as much as $40 \%$.
\end{abstract}

Keywords: Poultry litter, Subsurface application, Manure, Subsurfer, Nutrient management

\section{Introduction}

Poultry litter (manure mixed with bedding material) is a rich organic source of crop nutrients that also helps neutralize soil acidity by contributing significant quantities of calcium and magnesium (Mitchell and Donald, 1999). In areas where agricultural productivity has been hindered by low soil fertility, poultry litter applications have been used successfully to convert poor agricultural soils into highly productive crop land. Litter is commonly used to fertilize hay fields, pastures, and other no-till cropping systems where the only available application method has been to broadcast it on the soil surface. Unfortunately, this method leaves the litter 
exposed to the atmosphere, allowing valuable nutrients to be carried by storm runoff into nearby streams and lakes (McLeod and Hegg, 1984; Edwards and Daniel, 1993; Shreve et al., 1995; Sharpley et al., 2001) and causing substantial nitrogen losses as the ammonia volatilizes (Brady, 1990; Chapman and Snyder, 1992; Nathan and Malzer, 1994; Sharpe et al., 2004). To help address these problems, a research team at the USDA Agricultural Research Service (USDA-ARS) has developed a mechanized technique for applying dry poultry litter in shallow parallel bands beneath the surface of no-till agricultural systems (Pote et al., 2011).

Research on established perennial pasture showed that subsurface banding effectively prevented ammonia $\mathrm{N}$ losses (Moore et al., 2011; Fig. 1) and decreased litter nutrients lost in storm runoff by more than $90 \%$ compared to surface-broadcast litter applications (Pote et al., 2009; Fig. 2), while causing only minimal disturbance of the grass and soil structure. Subsurface litter application also decreased water loss by increasing the rain infiltration rate. Because subsurface banding increased retention of nutrients and water in the soil, the authors conducted a field study to compare crop yield and quality from this litter application method to those from the conventional surface broadcasting method. The objectives were to determine effects of subsurface application on perennial forage yield, quality, and temporal yield distribution during the growing season.

\section{Methods}

Field plots (dimensions $=2 \times 2 \mathrm{~m}$ ) for this study were located in a perennial pasture on Enders silt loam (Clayey, mixed, thermic Typic Hapludult) soil with $8-10 \%$ slopes in Logan County, Arkansas, USA $\left(35^{\circ} \mathrm{N}\right.$ latitude, $94^{\circ}$ $\mathrm{W}$ longitude). With occasional applications of commercial fertilizer, the well-established bermudagrass (Cynodon dactylon L.) and mixed grass forage crop had maintained approximately 100\% ground cover as measured by the line-transect method (Laflen et al., 1981). A fence constructed around the plots prevented any grazing, damage, or other livestock effects during the study.

Broiler litter (including rice hull bedding material) was collected from a commercial poultry house, mixed thoroughly, and stored in plastic bags at $4^{\circ} \mathrm{C}$ until applied to the plots. Sample analysis showed the litter contained the following component concentrations (\%): nitrogen (4.03), phosphorus (1.42), potassium (2.13), calcium (2.23), magnesium (0.47), sulfur (0.51), carbon (30.63), and water (23.6). Water content of the poultry litter was measured gravimetrically. Dry combustion of a litter sample was used to release the $\mathrm{C}$ and $\mathrm{N}$ as gases so that total $\mathrm{C}$ could be measured by infrared detection and total $\mathrm{N}$ measured by a thermal conductivity cell. Mineral concentrations were measured by digesting samples in concentrated $\mathrm{HNO}_{3}$ and $\mathrm{H}_{2} \mathrm{O}_{2}$ (Huang and Schulte, 1985), and analyzing with an inductively coupled plasma spectrophotometer (ICP-OES).

Early in the growing season, broiler litter was applied to each plot (except control plots) at a rate of $6.7 \mathrm{Mg} \mathrm{ha}^{-1}$ (dry weight), using one of two application methods: surface broadcast manually or subsurface banded using a single-shank, tractor-drawn, prototype implement (Fig. 3) that applies litter in a subsurface band. Treatments were randomly assigned to plots, with three replications of each treatment, for a total of nine plots including the controls. The prototype applicator implement sliced a shallow trench $(8-\mathrm{cm}$ deep, $5-\mathrm{cm}$ wide) in the soil surface (across the slope), poured litter into the trench, and covered it with soil. This was repeated at 30-cm intervals up the slope to provide the full litter application for each subsurface-banded plot. For surface applications, litter was broadcast manually over the plot as uniformly as possible, but the tractor was first driven over each plot to simulate effects of a litter spreader and minimize variability between treatments with regard to surface macropores or possible soil compaction effects.

Throughout the growing season, measurements of forage yield were taken at 28-day intervals by harvesting from the center area $(47 \mathrm{~cm} \times 107 \mathrm{~cm})$ of each plot down to a forage height of $5 \mathrm{~cm}$. Forage samples were dried in a forced-air oven at $60^{\circ} \mathrm{C}$ for 72 hours to obtain dry weights, and ground in a Wiley mill to 1-mm diameter particle size for quality analyses. Treatment effects on forage quality were determined by using a procedure described by Goering and Van Soest (1970), modified by eliminating use of a blender and steel-wool filtration, to assess in vitro digestibility; and by using a micro-Kjeldahl procedure to measure crude protein levels.

Experimental results were analyzed by using the general linear models (GLM) procedure to identify significant differences between the means (SAS Institute, 1996). Each mean represented three replications of the treatment. Results were compared to determine effects of subsurface litter application on forage yield and quality.

\section{Results and Discussion}

\subsection{Total Annual Forage Yield}

Results of this study clearly demonstrated the value of poultry litter for increasing forage yields; and showed that the amount of increase can be affected by litter application method, as subsurface-banded litter caused the greatest increase in forage yield. When compared to forage yield on control plots that received no litter, the 
single litter application more than doubled total forage yield for the season when surface broadcast, and more than tripled total forage yield when subsurface banded (Fig. 4). It is probable that subsurface litter application yielded the most forage at least partly because this method retained the most nutrients (especially N) in the soil to provide additional nourishment for the forage grasses.

\subsection{Temporal Distribution of Forage Yield during the Growing Season}

Litter application method had little effect on forage yield during the early part of the growing season (first hay cutting), but subsurface application significantly increased forage yields later in the growing season (second hay cutting). Why this effect of subsurface application was not apparent until the second cutting is uncertain, but it seems likely that much of the nitrogen from surface-applied litter had volatilized by then, while the extra time allowed litter nitrogen retained in the soil by incorporation to be mineralized by the soil microbial population and become more available to the forage. It is also possible that by the time the second cutting occurred, forage root growth had expanded into the subsurface litter bands, thus allowing the plants to better exploit litter nutrient reservoirs in the soil. In any case, the change in temporal distribution of forage yield during the growing season could have beneficial implications for livestock producers because litter incorporation tended to stimulate additional forage growth toward the latter part of the growing season when forage production from surface-applied litter often begins to decline. This could be especially helpful for spring calves that are not mature enough to fully utilize forage until late in the growing season.

\subsection{Forage Nutritive Value (Quality)}

Applying poultry litter under the pasture surface generally improved nutritive value of the forage crop, as it tended to increase both protein content and digestibility of the grass to levels above those found in forage from surface-broadcast litter. Nitrogen $(\mathrm{N})$ is a critical component of protein that is usually in limited supply for forage plants, and previous research has shown that increasing $\mathrm{N}$ applications on bermudagrass will increase the protein content (Burton and DeVane, 1951; Hill and Tucker, 1968; Burton et al., 1969). Therefore, subsurface application may also increase forage protein levels because it has been shown to decrease losses of litter $\mathrm{N}$ (Pote et al., 2003). This study supported that hypothesis by showing the subsurface application method increased protein content of the forage crop (Fig. 5).

Forage was generally more digestible when fertilized with poultry litter, especially when the litter was applied by the subsurface method. In every cutting, the digestible dry matter content consistently measured highest in forage from plots where the litter was subsurface banded, but the difference was not always significant at the $\alpha=0.05$ level (Fig.6). Previous research (Croy and McCroskey, 1971) has shown that increasing applications of N can increase the digestibility of grass forage. Therefore, it seems likely that increases in digestibility observed in our study may have been a result of the subsurface application method controlling $\mathrm{N}$ losses, thus retaining greater amounts of $\mathrm{N}$ in the soil for utilization by the forage crop.

\section{Conclusions}

This study clearly demonstrated the agronomic value of poultry litter for livestock production on perennial pasture; but also showed that subsurface banding the litter application resulted in higher annual forage yield and better forage quality than when the litter was surface broadcast. Applying poultry litter under the pasture surface tended to increase both protein content and digestibility of the grass to levels above those found in forage fertilized with surface-broadcast litter. The subsurface litter banding method also changed temporal distribution of forage yield during the growing season, yielding more forage than surface-broadcast litter primarily in the latter part of the season (second forage cutting). Because subsurface-banded litter increased yield at a time when forage production from surface-broadcast litter often begins to decline, it may provide added benefits for livestock, especially to spring calves that are not mature enough to fully utilize forage until late in the growing season.

It should be noted that differences in crop yield and quality may vary greatly from one season to the next because they are influenced by several factors such as weather, nutrient availability, soil, and disease. Because this study did not utilize excessive nutrient applications and was conducted when rainfall and other growing conditions were favorable for crop growth, it was able to demonstrate potential increases in productivity that can be achieved when nutrients are used more efficiently. Although subsurface application can offer more efficient use of applied nutrients, that may have little impact on yield or quality under some growing conditions. For example, if water is scarce or the crop has been heavily fertilized and already has sufficient nutrients available, then using nutrients more efficiently may have little impact on crop productivity in the short term. Under such conditions, the primary benefits of subsurface application may be its ability to help prevent odor problems and environmental degradation. 


\section{Further Development of Subsurface Application Technology}

The USDA-ARS research team that developed subsurface banding technology for dry poultry litter has continued to work toward making this application method into a practical management option for farmers. A more advanced tractor-drawn prototype, the Adjustable-Band applicator constructed at the National Soil Dynamics Laboratory (Auburn, AL), uses four trench openers to apply poultry litter in four subsurface bands simultaneously with adjustable band spacing and side-dressing capability for row crops. A more recent advance in the technology was construction of the "Subsurfer" prototype, a larger machine developed at the Dale Bumpers Small Farms Research Center (Booneville, AR). This applicator, designed initially with fixed 30-cm trench spacing for perennial pastures, can transport $4.5 \mathrm{Mg}$ (5 tons) of dry untreated poultry litter directly from the poultry house and deliver a consistent flow of litter into eight parallel subsurface bands simultaneously.

When these prototypes were used to apply dry litter on no-till corn fields in Maryland, they significantly increased corn yields (20-36\%) compared to equivalent amounts of surface-broadcast litter (Fig. 7). The latest Subsurfer prototype (Fig. 8) has 24-cm trench spacing and is being field tested to prepare for possible commercial production in late 2012. Development of these prototypes for subsurface application of dry poultry litter has also generated considerable interest in possibly using them to apply other dry bulky soil amendments such as biochar or compost.

\section{Take-Home Message}

Development of subsurface application technology may soon provide farmers with a practical management option that helps increase nutrient-use efficiency, protect water quality, and prevent odor problems. Farmers can prevent major losses of valuable nutrients through ammonia volatilization and storm runoff by placing poultry litter directly into the root zone of no-till crops rather than broadcasting on the surface runoff zone. Subsurface applicators can further improve nutrient-use efficiency by helping farmers control the precision and uniformity of litter applications, including very low rates that are not feasible when using conventional broadcast spreaders.

\section{Acknowledgments}

This research was entirely funded by the U.S. Department of Agriculture - Agricultural Research Service (USDA-ARS). We gratefully acknowledge Stephen Haller, Marlin Siegford, Karen Chapman, and Tammy Horton (USDA-ARS) for their technical assistance in this research.

\section{References}

Brady, N.C. (1990). The nature and properties of soils. $10^{\text {th }}$ ed. Macmillan Publ., New York.

Burton, G., \& DeVane, E.H. (1952). Effect of rate and method of applying different sources of nitrogen upon the yield and chemical composition of bermudagrass hay. Agron. J., 44, 128-132. http://dx.doi.org/10.2134/agronj1952.00021962004400030006x

Burton, G., Wilkinson, W.S., \& Carter, R.L. (1969). Effect of nitrogen, phosphorus, and potassium levels and clipping frequency on the forage yield and protein, carotene, and xanthophyll content of Coastal bermudagrass. Agron. J., 61:60-63. http://dx.doi.org/10.2134/agronj1969.00021962006100010020x

Chapman, S.L., \& Snyder, C.S. (1992). Soils and fertilizers. Information Article 2-92. University of Arkansas Cooperative Extension Service.

Croy, L., \& McCroskey, J.E. (1971). Influence of nitrogen rates and seasons on bermudagrass quality. Okla. Agric. Exp. Sta. Prog. Rpt. P-646.

Edwards, D.R., \& Daniel, T.C. (1993). Effects of poultry litter application rate and rainfall intensity on quality of runoff from fescuegrass plots. J. Environ. Qual., 22, 361-365. http://dx.doi.org/10.2134/jeq1993.00472425002200020017x

Goering, H.K., \& Van Soest, P.J. (1970). Forage fiber analyses (apparatus, reagents, procedures, and some applications). Agric. Handbook, 379. ARS, USDA, Washington, DC.

Hill, W., \& Tucker, B.B. (1968). A comparison of injected anhydrous ammonia into bermudagrass sod compared to topdressed applications of urea and ammonium nitrate. Soil Sci. Soc. Amer. Proc., 32, 257-261. http://dx.doi.org/10.2136/sssaj1968.03615995003200020028x

Huang, C.L., \& Schulte, E.E. (1985). Digestion of plant tissue for analysis by ICP emission spectroscopy. Commun. Soil Sci. Plant Anal., 16, 943-958. http://dx.doi.org/10.1080/00103628509367657

Laflen, J., Amemiya, M., \& Hintz, E.A. (1981). Measuring crop residue cover. J. Soil Water Conserv., 6, 341-343. 
McLeod, R.V., \& Hegg, R.O. (1984). Pasture runoff water quality from application of inorganic and organic nitrogen sources. J. Environ. Qual., 13, 122-126. http://dx.doi.org/10.2134/jeq1984.00472425001300010022x

Mitchell, C.C., \& Donald, J.O. (1999). The value and use of poultry manures as fertilizer. Alabama Cooperative Extension Publication ANR-244.

Moore, P.A., Jr., Miles, D.M., Burns, R., Pote, D.H., Berg, W.K., \& Choi, I.H. (2011). Ammonia emission factors from broiler litter in barns, in storage, and after land application. J. Environ. Qual., 40, 1395-1404. http://dx.doi.org/10.2134/jeq2009.0383

Nathan, M.V., \& Malzer, G.L. (1994). Dynamics of ammonia volatilization from turkey manure and urea applied to soil. Soil Sci. Soc. Am. J., 58, 985-990. http://dx.doi.org/10.2136/sssaj1994.03615995005800030050x

Pote, D.H., Kingery, W.L., Aiken, G.E., Han, F.X., Moore, P.A., Jr., \& Buddington, K. (2003). Water-quality effects of incorporating poultry litter into perennial grassland soils. J. Environ. Qual., 32, 2392-2398. http://dx.doi.org/10.2134/jeq2003.2392

Pote, D.H., Way, T.R., Sistani, K.R., \& Moore, P.A., Jr. (2009). Water-quality effects of a mechanized subsurface-banding technique for applying poultry litter to perennial grassland. J. Environmental Management, 90, 3534-3539. http://dx.doi.org/10.1016/j.jenvman.2009.06.006

Pote, D.H., Way, T.R., Kleinman, P.J.A., Moore, P.A., Meisinger, J.J., \& Sistani, K.R., et al. (2011). Subsurface application of poultry litter in pasture and no-till soils. J. Environ. Qual., 40, 402-411. http://dx.doi.org/10.2134/jeq2010.0352

SAS Institute. (1996). SAS System for Windows. Release 6.12. SAS Inst., Cary, NC.

Sharpe, R.R., Schomberg, H.H., Harper, L.A., Endale, D.M., Jenkins, M.B., \& Franzluebbers, A.J. (2004). Ammonia volatilization from surface-applied poultry litter under conservation tillage management practices. $J$. Environ. Qual., 33, 1183-1188. http://dx.doi.org/10.2134/jeq2004.1183

Sharpley, A.N., McDowell, R.W., \& Kleinman, P.J.A. (2001). Phosphorus loss from land and water: Integrating agricultural and environmental management. Plant and Soil, 237, 287-307.

Shreve, B.R., Moore, P.A. Jr., Daniel, T.C., Edwards, D.R., \& Miller, D.M. (1995). Reduction of phosphorus in runoff from field-applied poultry litter using chemical amendments. J. Environ. Qual., 24, 106-111. http://dx.doi.org/10.2134/jeq1995.00472425002400010015x

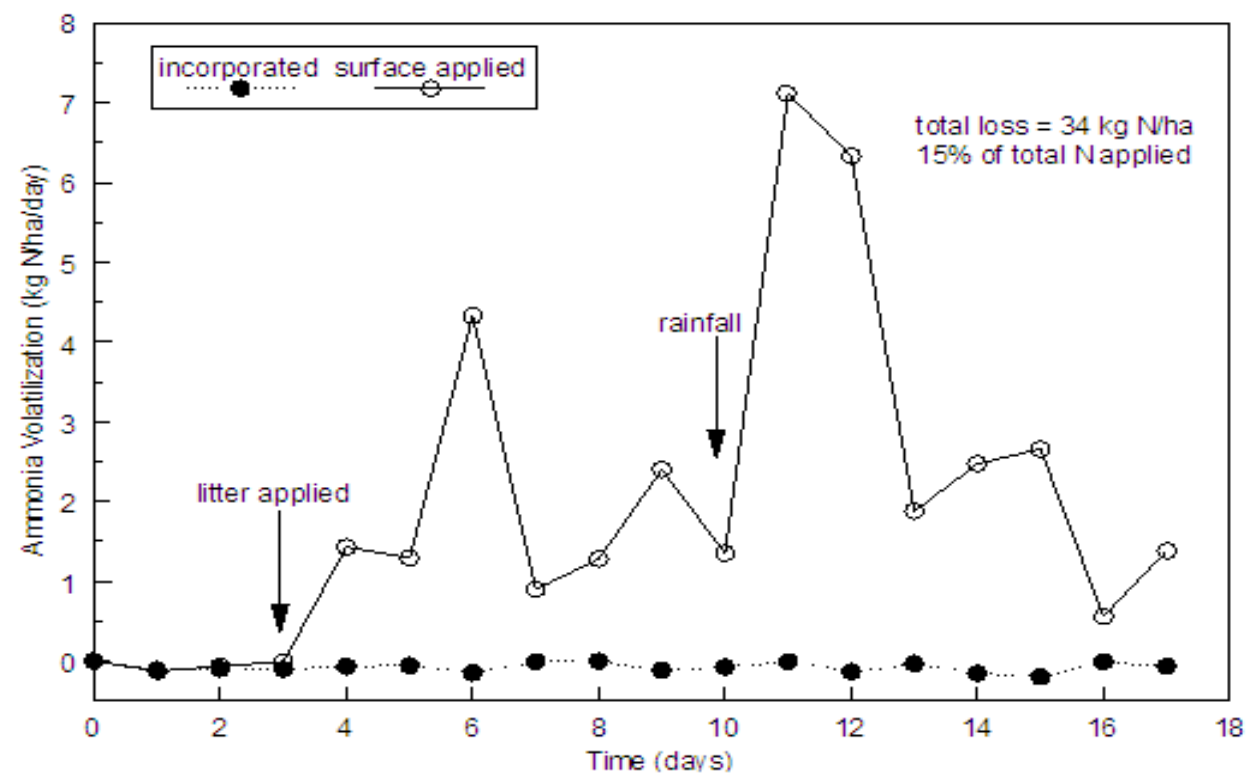

Figure 1. (adapted from Moore et al., 2011). Effect of litter application method on ammonia volatilization from dry poultry litter applied $(5.6 \mathrm{Mg} / \mathrm{ha})$ to perennial pasture 


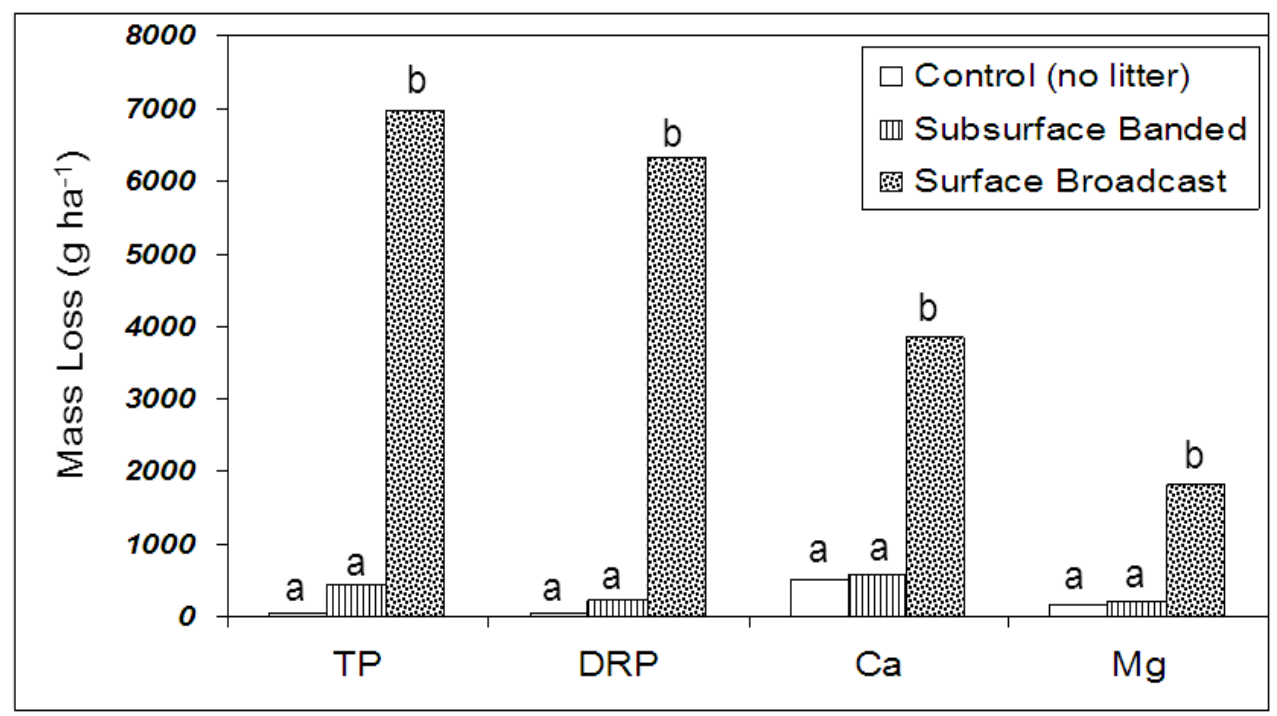

Figure 2. (adapted from Pote et al., 2009). Effect of litter application method on losses of total phosphorus (TP), dissolved reactive phosphorus (DRP), calcium, and magnesium in runoff from perennial pasture receiving dry poultry litter at $6.7 \mathrm{Mg} / \mathrm{ha}$. For each runoff component, bars with the same letter indicate treatment results that were not significantly different $(\alpha=0.05)$

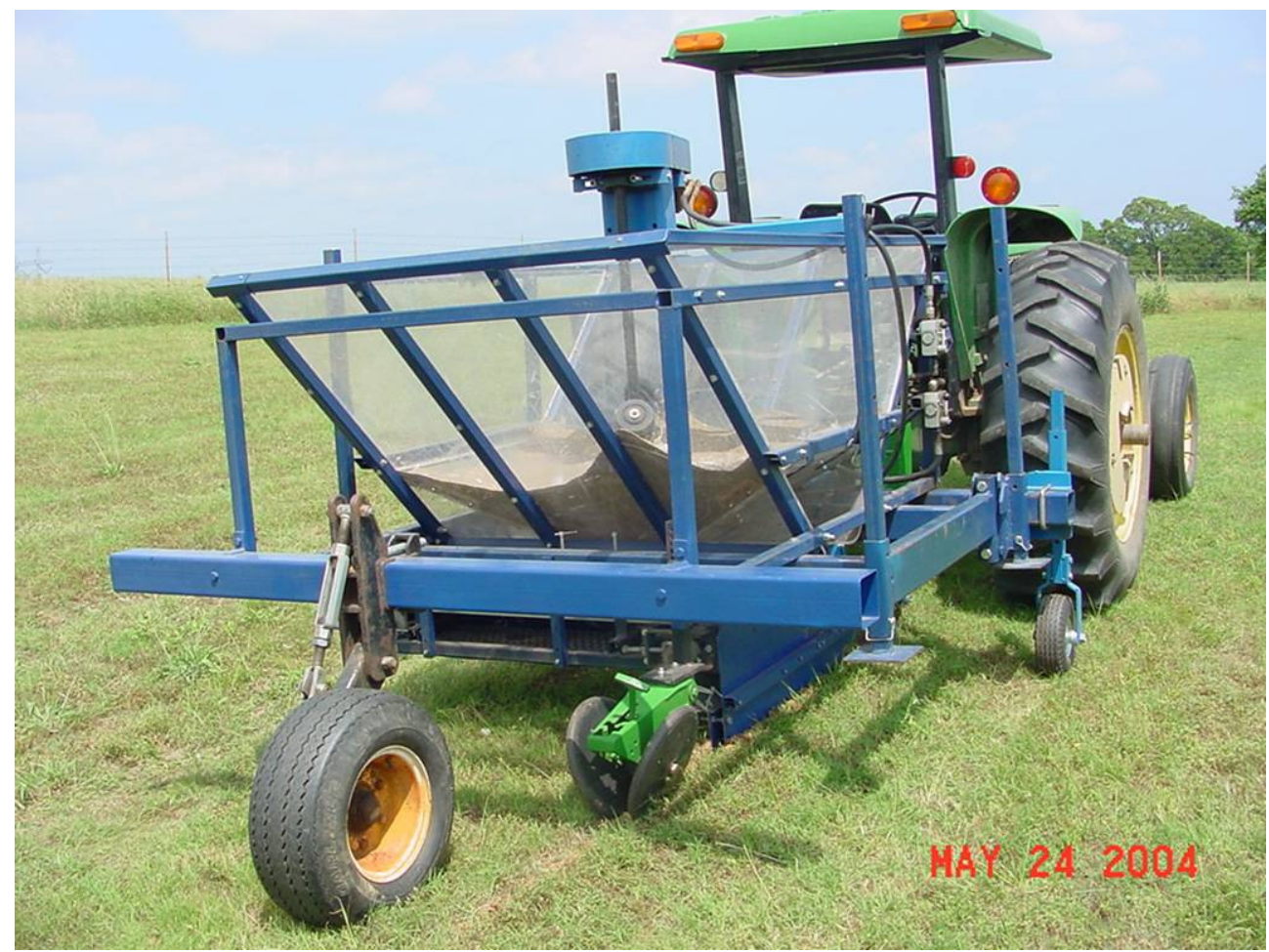

Figure 3. (adapted from Pote et al., 2011). Single-shank prototype implement developed at USDA-ARS National Soil Dynamics Laboratory (Auburn, AL) for subsurface application of dry poultry litter 


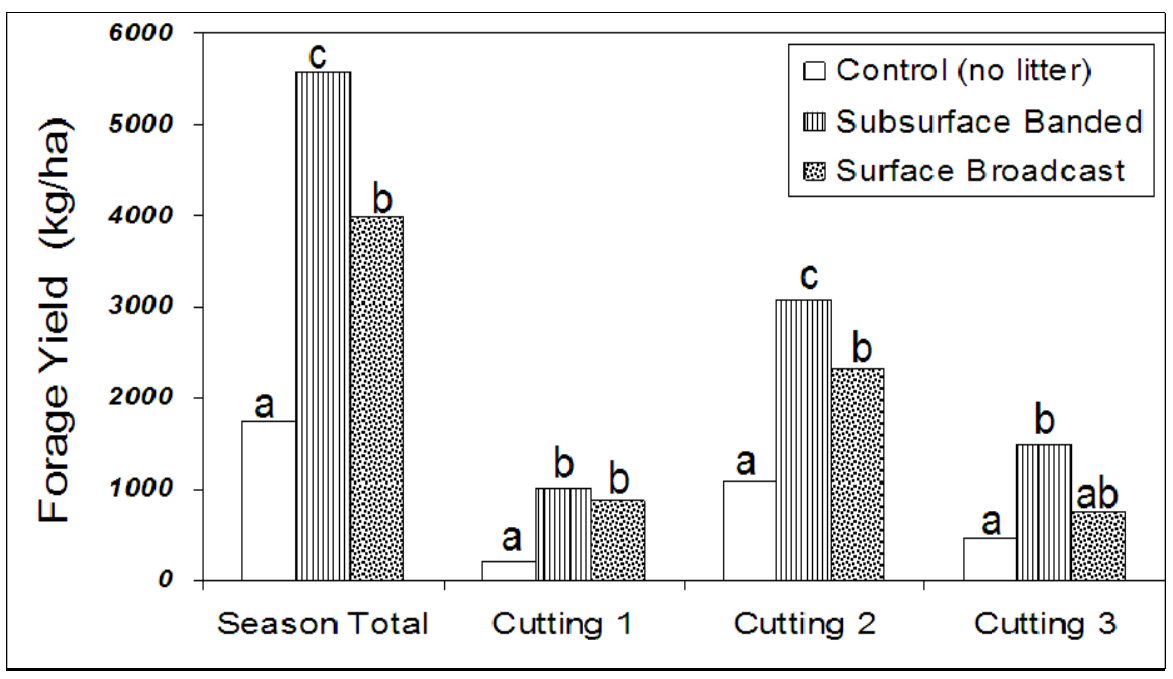

Figure 4. Effect of litter application method on dry-weight forage (bermudagrass) yield from perennial pasture receiving dry poultry litter at $6.7 \mathrm{Mg} / \mathrm{ha}$. Within each group, bars with the same letter indicate no significant difference $(\alpha=0.05)$ in forage yields

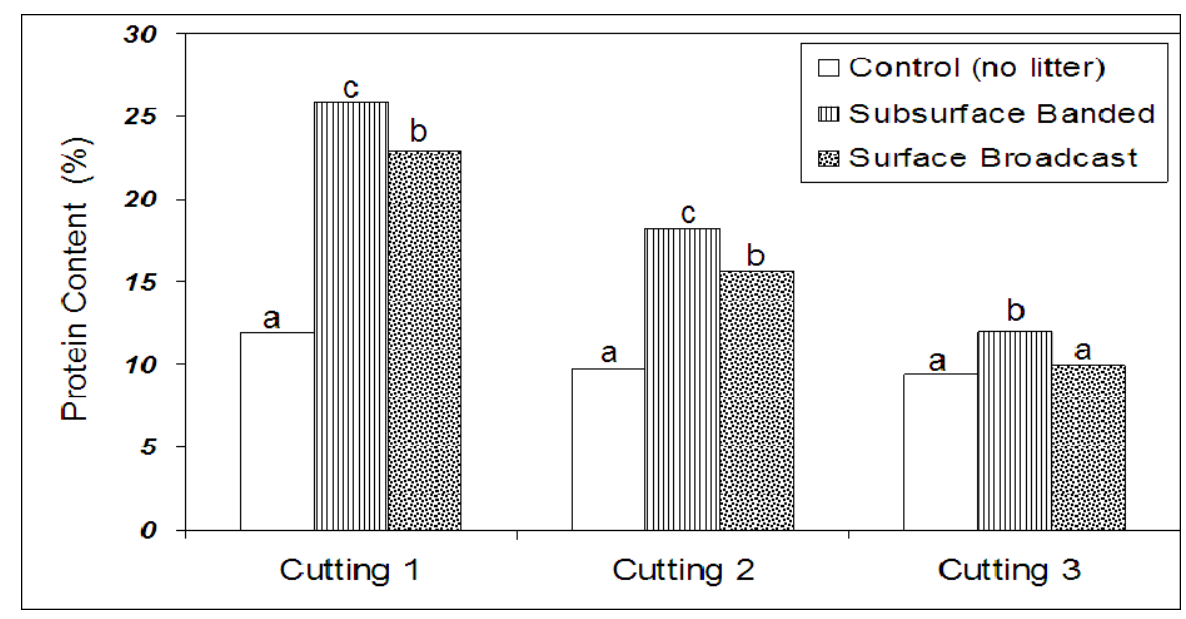

Figure 5. Effect of litter application method on forage (bermudagrass) protein content for perennial pasture receiving dry poultry litter at $6.7 \mathrm{Mg} / \mathrm{ha}$. Within each cutting, bars with the same letter indicate no significant difference $(\alpha=0.05)$ in protein content

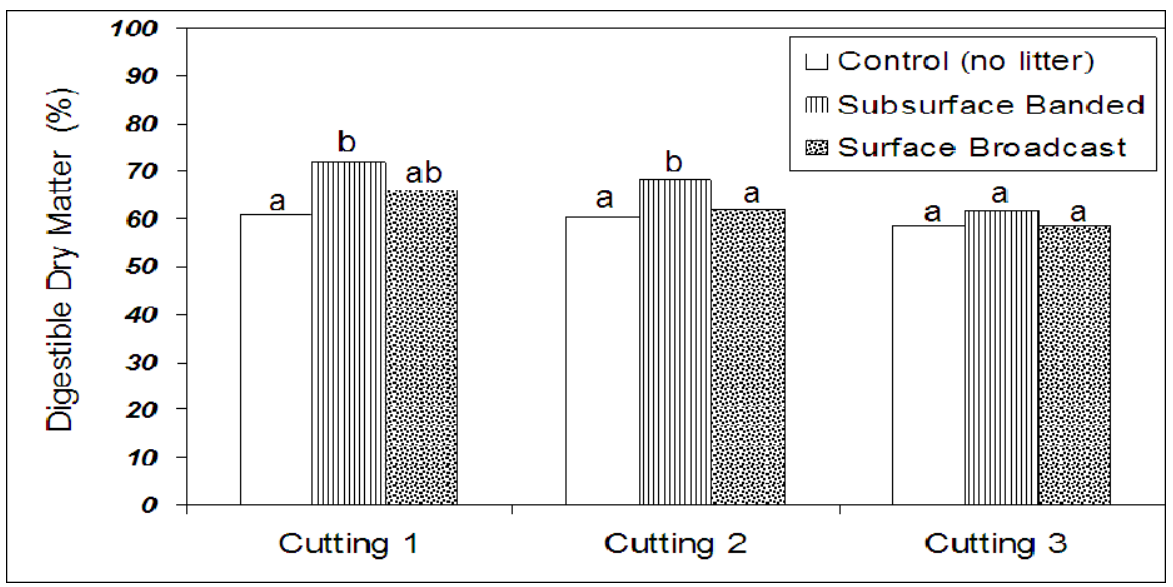

Figure 6. Effect of litter application method on forage (bermudagrass) digestibility for perennial pasture receiving dry poultry litter at $6.7 \mathrm{Mg} / \mathrm{ha}$. Within each cutting, bars with the same letter indicate no significant difference $(\alpha=0.10)$ in digestibility 


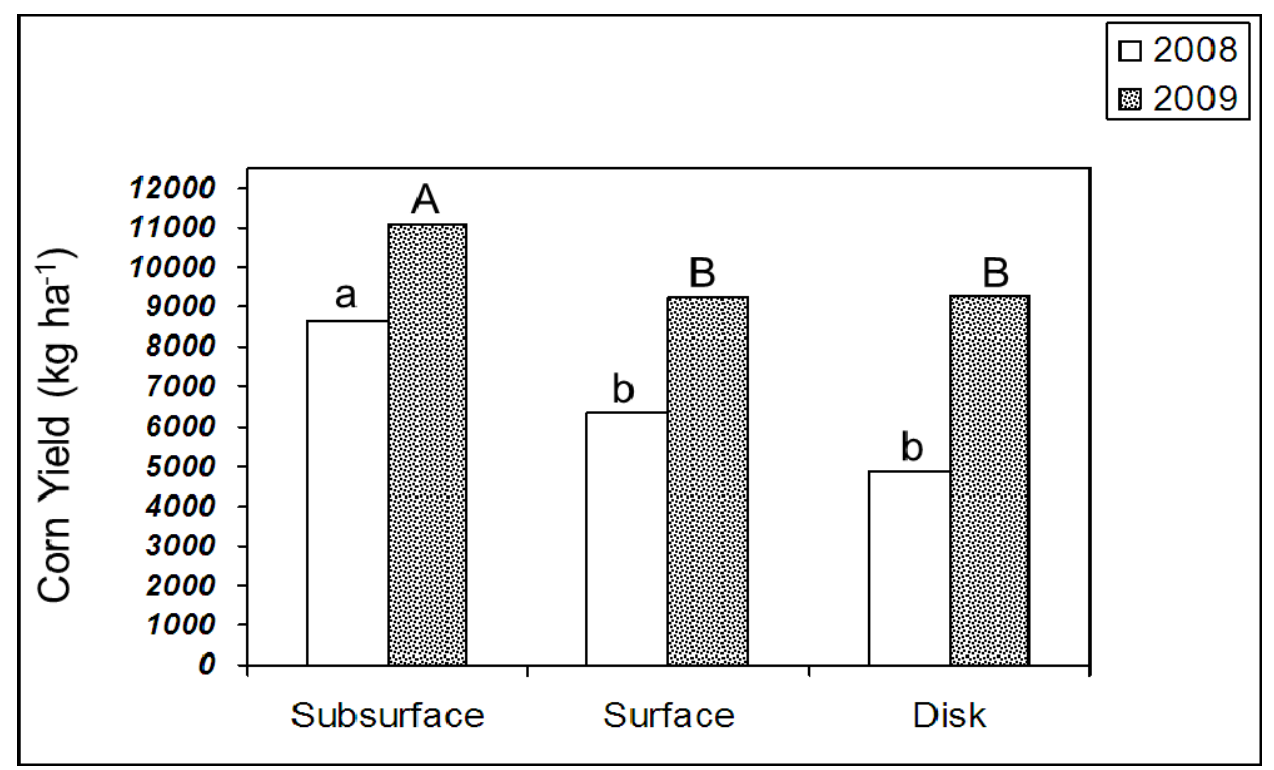

Figure 7. (adapted from Pote et al., 2011). Effect of litter application method on corn yields from no-till fields in Maryland fertilized with dry poultry litter at $6.7 \mathrm{Mg} / \mathrm{ha}$. Subsurface application was accomplished using the USDA-ARS Adjustable-Band prototype applicator in 2008 and the USDA-ARS Subsurfer in 2009. For each year, bars with the same letter indicate corn yields that were not significantly different $(\alpha=0.05)$

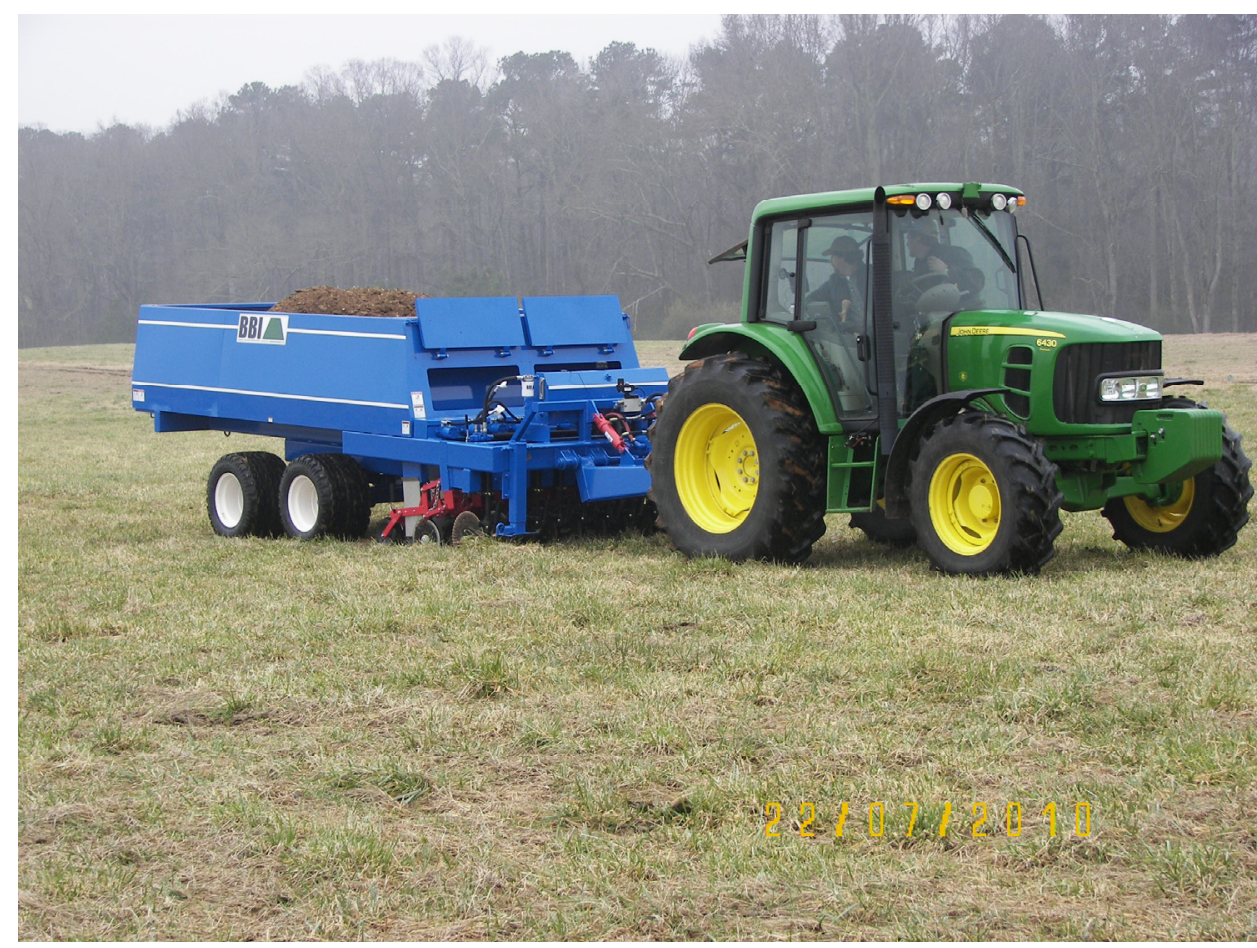

Figure 8. Poultry Litter Subsurfer prototype developed at the USDA-ARS Dale Bumpers Small Farms Research Center (Booneville, AR) for subsurface application of dry poultry litter 